\title{
Accounting Theory Lenses to Analyze Literature: An Exploration through Shakespeare's Macbeth
}

\author{
Patrice Gélinas $^{1 *}$, Camilia Gélinas ${ }^{2}$, Lisa Baillargeon ${ }^{3}$ \\ ${ }^{1}$ Faculty of Liberal Arts \& Professional Studies, York University, Toronto, Canada, \\ ${ }^{2}$ Faculty of Arts, McGill University, Montreal, Canada, \\ ${ }^{3}$ École des sciences de la gestion, ESG-UQAM Montreal, Canada
}

Corresponding Author: Patrice Gélinas, E-mail: gelinas@yorku.ca

\section{ARTICLE INFO}

Article history

Received: May 13, 2018

Accepted: August 04, 2018

Published: November 01, 2018

Volume: 7 Issue: 6

Advance access: September 2018

Conflicts of interest: None

Funding: None

\begin{abstract}
The present study is the first of its kind to suggest that accounting theory lenses can be a powerful tool to understand literary works, such as a diegesis. Using Shakespeare's Macbeth as exploratory setting, we propose a metaphorical abstraction process to translate and analyze characters and currencies. We then illustrate the effectiveness of an accounting theoretical framework to analyze a sample of play events which allude to its finality. The main contribution of this paper is to illustrate how the work of literature and accounting theorists can be mutually illuminating.
\end{abstract}

Key words: Shakespeare, Accounting Theory, Interdisciplinary Approaches In Literature, New Economic Criticism

\section{INTRODUCTION}

\section{Aim and Goals}

This paper contends that accounting theory could be powerful framework to understand literature and, consequently, a new and promising interdisciplinary analytical tool for literature researchers. Our first goal is to demonstrate how accounting theory can be used to explore literature and our second goal is to provide an illustrative application through an analysis of Shakespeare's Macbeth (ca. 1606).

More specifically, this paper explores how the diegesis of Macbeth may be understood, and even anticipated, through an accounting theory framework and suggests a metaphorical systematization of human behavior and governance mechanisms as analytical lenses. More generally, this paper's aim is to propose that accounting theory could represent powerful theoretical lenses to analyze situations and settings far removed from accounting issues.

In 1494, about a century before Macbeth was first performed on stage, Luca Pacioli published Summa de Arithmetica, Geometria, Proportioni et Proportionalita, a work that marked the birth of the double entry system of accounting. Pacioli's method endures to this day despite the ever increasing complexity of business environments (Sangster, 2016). This turning point in accounting history - the amalgamation of mathematical concepts with what was then considered a human science, an art, or even a language - has led New Economic Criticism scholars to posit that "money, commerce and economics make a good deal of difference to English Renaissance Literature" in general, and notably in Shakespeare's work as well (Woodbridge, 2003, page vii). The empirical setting that Shakespeare scholars would spontaneously recommend to detect the impact of money, commerce and economics on Shakespeare's work is The Merchant of Venice (Shakespeare, 1600; West, 2016). However, there is evidence that the repercussions are far more widespread throughout the Shakespearean corpus (see Raman, 2005; Korda, 2009).

The success of the hybridization of mathematics and human science may stem from the resulting language of business by which accounting is described (Avery, 1953). Indeed, common vocabulary, agreed-upon meanings, and standardized codes and modes of presentation allow for the universalisation of the art and science of accounting in its application to different fields of practice and study.

\section{Empirical Setting}

In this study, we explore the boundaries of the accounting framework's ability to help understand, and even predict, events and human behaviour in literature by revisiting parts of a dramaturgy masterpiece through the lenses of accounting theory.

We selected Macbeth, one of William Shakespeare's tragedies, as empirical setting. It was produced a century after Pacioli's seminal publication. In his plays, the English playwright explores human nature when confronted with critical contexts. Macbeth presents the conflict between the 
preservation of honor and the promise of immediate power (see Dobski \& Gish, 2011; Watson, 1960) or, in freely-translated accounting terms, the conflict between presenting an accurate portrayal of one's situation contrasted with the immediate private gains that can be exerted from managing impressions. This simple reformulation reveals interesting questions: is it possible to discern the occurrence of well-documented behavioral accounting issues in a tragic play? For instance, is it conceivable in Macbeth's diegesis? At a more general level, could accounting theory be a new lens to analyse literature? We believe so. At their roots, both accounting theory and tragedy are means to explore human nature.

In an attempt to respond to these interrogations, a selection of intrigues involving the main family of the play, the Macbeths, is analyzed through accounting theory lenses, as if the clan were an (economic) entity. The next section reviews new economic criticism arguments in favor of exploring literature with theories rooted in economic fields. The following section describes the main features of positive accounting theory. We then specify the analogies we use to probe the faith of the Macbeth family through accounting theory lenses, and we present the results of our analysis in the subsequent section before concluding.

\section{Economically-Rooted Theories to Illuminate Literature}

Originating in the late 1970s, a growing body of literature, labeled the New Economic Criticism paradigm, explores the myriad ways in which economics and literature are mutually illuminating. Positive accounting theory is a close sibling (many would argue an offspring) of economic theory.

A first branch of new economic criticism employs economic principles and paradigms to offer novel readings of literary and theoretical texts. This movement extends literary scholarship towards historically informed methods, and interrogates those methods by exposing the material conditions under which texts were produced. Illustrative papers include: Heinzelman (1980), Shell (1978, 1982, 1995), Purdy (1993), Resnick \& Wolff (1988), Klamer et al. (1988), McKlowskey (1985), Amariglio (1990), Jameson (1991), Kaufmann (1995), Rossi-Landi (1975) and Solow (1988).

A second branch of new economic criticism includes work by economists schooled in feminist, literary and cultural theory. It suggests alternatives to the constraining models that dominate neoclassicism (Woodmansee \& Osteen, 1999).

A third branch of new economic criticism is probing literary works for economic and managerial insights. An example is a paper by Surbi Kapur and Pooja Mohanty (2014), "Lessons from Literature: Blending Academic Perspective with Management Practices". These authors note that:

"Shakespeare's Macbeth also teaches us the importance of the ability to differentiate between things that lead us to certain definite results - the ability to understand where to stop and the ability to take decision. Decision-making is a very important aspect of management." (2014, p.235)

The latter quote suggests that accounting theory should be a promising analytical framework, given that one of the main purposes of accounting is to inform decision-making. Consistently, Natasha Korda (2009) adds:

"The language of (ac) counting in these and other dramatic texts is richly suggestive of the central role played by bookkeeping and formal instruments of credit, such as bonds, in the expanding credit economy that gave rise to the commercial theaters." (2009, p. 130)

New economic criticism is known to fruitfully examine texts for their economic form, content, and contexts, and furnishes new perspectives on cultural and economic history. Prominent monographs include that of Linda Woodridge (2003) entitled Money and the age of Shakespeare: essays in new economic criticism, as well as The new economic criticism: Studies at the intersection of literature and economics by Martha Woodmansee and Mark Osteen (1999).

An interesting conclusion drawn from Woodbridge's exploration of Shakespeare is that a reading of his works through economic lenses reveals the cultural ubiquity of an accounting mentality and of quantitative thinking. It further shows that money crosses the frontier between price and pricelessness.

Building on this evidence of accounting mentality and quantitative thinking at the time of the creation of Shakespeare's works, this paper seeks to contribute to the development of new economic criticism and interdisciplinary approaches in literature by suggesting a rigid accounting theory framework to analyze how Shakespeare's characters may have applied their quantitative thinking to non-financial decisions, and may also have fallen in the behavioral trap of impression management and fraudulent behavior that continue to be well-documented in the accounting literature (see Healy \& Wahlen, 1999). In doing so, we propose a metaphorical license to assign a value to what can be regarded as priceless.

\section{Hypothesis and Research Design}

This paper hypothesises that accounting theory, and positive accounting theory in particular, can be a powerful framework to analyse literary work. To provide support for this hypothesis, we first present positive accounting theory. We follow by proposing an abstraction process to adapt business concepts to the literary concepts most appropriate for the Macbeth setting. We then illustrate how accounting theory can help to understand Macbeth in a novel way. This paper is important because it proposes a new, powerful and adaptable theoretical framework to analyse literary work.

\section{POSITIVE ACCOUNTING THEORY}

This paper submits accounting theory to an abstraction process allowing for the analysis of a selected dramatic play. We focus on the most prominent paradigm of accounting theory, positive accounting theory, which builds on many specialized applications of agency theory (Jensen and Meckling, 1976).

Positive accounting theory (Watts \& Zimmerman, 1986) contends that actors may choose accounting methods displaying either an efficient or an opportunistic perspective. In 
an efficient setting, managers portray, through record keeping and disclosure, an accurate representation of the firm's situation. By contrast, in an opportunistic setting, managers depict the firm's transactions and situation less accurately in a manner as to maximize their own utility, most often than not to the detriment of other stakeholders.

\section{Opportunistic Perspective}

A first research branch of the positive accounting theory's opportunistic perspective is the management compensation hypothesis (Deegan, 2014). Compensation arguments can help to explain deceitful accounts of a firm's activity when, for instance, the firm manager can draw private, or personal, gains from misrepresenting the transactions and results of the firm. A second research branch of the opportunistic perspective is the political cost hypothesis. Political arguments are concerned with the manager's goal of downplaying a firm's wealth in order to avoid attracting the attention of authorities with taxation or regulatory powers. The third branch of the opportunistic perspective is the debt/equity perspective, which states that managers will tend to disclose a better financial situation than reality if in doing so they increase their chances of obtaining better credit conditions from lenders (Deegan, 2014). Examples of empirical evidence supporting the accounting theory's opportunistic perspective include Zang (2011), Erickson et al. (2006) and Burgstahler \& Dichev (1997).

\section{Agency Perspective}

Agency theory (Jensen \& Meckling, 1976), another pillar of accounting theory rooted in the theory of the firm, theorizes selfish and opportunistic behavior by non-owner firm managers when governance systems do not allow for the perfect monitoring of their actions. A direct prediction of agency theory is therefore the design of governance mechanisms to limit agency costs.

According to accounting theorists interested in impression management, inefficiency or opportunistic misrepresentation for private benefit can be concealed for a while but, when discovered or unsustainable, lead to fraudulent behavior to become, ultimately, fatally costly (Healy \& Whalen, 1999; Karpoff et al., 2008; Ball, 2009). High profile illustrative cases of corporate failures include the demise of firms such as Enron and Worldcom (Ball, 2009; Healy \& Palepu, 2003).

\section{Classic Illustrative Business Case}

In their 2003 paper, Paul Healy and Krishna Palepu explain how the concealment of true performance through a series of maneuvers led to the rise of Enron as one of the world's most admired and valuable companies to its rapid downfall to bankruptcy and to the status of poster child for earnings management and corporate malfeasance. Consistent with the opportunistic perspective of positive accounting theory, the authors identify governance and incentive problems leading to this tragic failure.
The Enron case, like many others, is one where managers extract private gains and privileges (compensation, equity value, perquisites) by providing stakeholders with a wrong impression about the firm's value and performance. To maintain private gains and privileges despite deceitful true results, accounting and financial maneuvers must be continually more elaborate and risky, and eventually fraudulent, until they ultimately become discovered as inadequate portrayals of the firm's reality. When deceitful maneuvers are discovered, the firm loses the trust of its creditors and shareholders, leading to a rapid downfall. Studies about perpetrators of financial deception suggest these individuals are typically overconfident, which makes them "more likely to start down a slippery slope of growing intentional misstatements". Overconfidence also leads them to believe that they will somehow, and despite the odds, turn things around and get away with misstatements and fraud undiscovered, and without consequences in the end (Schrand \& Zechman, 2012).

\section{METHOD TO USE ACCOUNTING THEORY LENSES TO ANALYSE LITERARY WORK}

\section{Abstraction Process}

The analysis of literary work through accounting theory lenses requires a number of abstractions. First, let's consider a play character as a firm with the firm manager as its brain. The firm may be part of a broader (economic) entity, or itself be an economic entity, depending on how the firm, or character, is governed. This analogy is both straightforward and challenging since firms are widely recognized as legal persons (Sheppard, 1994). Analogously, characters of the play complete transactions and generate results over time. However, notions of control and significant influence command more discussion. In strict accounting terms, control is recognized when it can be asserted without the cooperation of others. A narrow analogical interpretation would suggest that it applies only to enslaved or subjugated characters. However, let's stretch the interpretive licence to a much more fertile analytical ground and see each character as a firm which can be controlled by different forms of agreements, but which is also led by a brain (or manager) that can be self-interested, deceitful, faithful, subjected to predation from outside forces, long-lived, short-lived, acting on behalf of more than one master, seized by greater powers, controlling other characters itself, have significant influence over others, and much more.

\section{Characters}

It is then possible to assemble these characters in affiliated groups, or economic entities. Logic commands that such a type of groups share common interests and goals. For example, in the context where Macbeth is couched, the most plausible human and social analogy to a modern-day conglomerate is a family. Ipso facto, in this study, families are viewed as economic entities, an assumption corresponding to the contemporary corporate reality in many countries around the world (Fogel, 2006). 


\section{Currency}

Second abstraction is the concept of currency. Again, a literal study of monetary exchanges in most plays would lead to rather poor empirical settings. Let's broaden the transposition to a literary context that does not include an exact homologue. In Macbeth's case, we stretch the analogical licence to using honor as the play's main currency. We note that an analytical currency could vary from a setting, or diegesis, to another, just like it varies from one economical setting to another. Like all currencies, honor has no intrinsic value unless there is a societal agreement on what it is worth and how it can be used (Pigou, 1917).

Honor must be qualified: two types of honor exist. The first type, social honor, is associated with status, appearance and the "exterior perspective". The closer characters get to the royal crown, the more social honor they acquire. Social honor can be accumulated following investment and effort, and may be lost following a detrimental transaction or an ill-timed one. The second type is moral honor, which regards conscience, the concept of good and evil, and the true legitimacy of actions. It can be gained by accumulating noble actions or transactions and lost by completing socially unacceptable ones.

In the play, it appears necessary to consider both social and moral honor as our metaphorical currency. This is revealed in Banquo's response to Macbeth's proposal of acquiring social honor: "So I lose none/In seeking to augment it" (II.i.32-33), which suggests that social and moral honor are both valuable, and that Banquo would not sacrifice moral honor to gain its equivalent in social honor.

\section{Wealth}

Continuing on the analogy, the wealth of a character or family may thus be akin to its honorific equity, the net difference between its honor assets and liabilities, following a number of actions and transactions. Consistently, power is the ability to control how this equity (or honorific wealth) will be used by all constituents of an entity.

Consistent with agency theory, a king can promise honorific wealth and use it as a governance mechanism over a selection of his subjects, such as guards and army, in return for behavior aligned with royal interests without direct monitoring.

\section{ANALYSIS OF MACBETH: FROM HONOR MANAGEMENT TO FRAUD TO FAILURE}

Relying on our accounting theory framework and the abstraction process, we now probe into illustrative events which can help to understand and anticipate the conclusion of Macbeth's diegesis. Our illustrative sample selection is designed to answer the following questions:

- Are there observable character actions and behaviours consistent with what the accounting theory's opportunistic perspective would predict?

- Are there observable character actions and behaviours consistent with what the accounting theory's debt-equity hypothesis would predict?
- $\quad$ Are there observable character actions and behaviours allowing for the prediction, through accounting theory lenses, of the tragic downfall of the Macbeth family?

\section{Opportunistic Perspective}

Accounting theory's opportunistic perspective anticipates that actors have an incentive to obfuscate their real actions and results in order to benefit from private gains, such as higher compensation (or greater honor in our case), or favorable treatment from third parties (e.g., lenders) or interest groups.

In the play, the concealment of information is clearly part of Macbeth's strategy to improve his honor because he dissimulates crucial information regarding the reality of the family's accumulated honorific wealth. For instance, when becoming king, Macbeth merely mentions to his wife his intention to conduct certain actions: "Strange things I have in head, that will to hand" (III.iv.160). Further, he never reveals their full extent, thereby obfuscating honor-decreasing moves which would undoubtedly reduce the honorific wealth of the family if discovered. When Lady Macbeth questions him on his intentions towards Banquo and Fleance, he states his will to keep some information from her: "Be innocent of the knowledge, dearest chuck/Till thou applaud the deed" (III.ii.50-51). He therefore keeps her and others from knowing past honor-decreasing actions, such as the sacrifice of moral honor by the murder of a man and his child. As Macbeth steps further into tyranny, he and his wife are drawn apart, making him ever less inclined to share the details of his actions and intentions, and increasingly forced to "window dress" his true actions.

The opportunistic perspective can also be useful lenses to analyse how Macbeth portrays himself in the eyes of his subjects and allies. He systematically eliminates anyone, including his best friend Banquo, who can potentially contest his "rightful" claim to power. This attempt to maintain favorable honorific equity results in tyranny terrorizing all of Scotland, and which Ross sadly describes to Macduff when he finds him in England: "Alas, poor country,/Almost afraid to know itself. It cannot/Be called our mother, but our grave; where nothing/But who knows nothing is once seen to smile" (IV. iii.184-87). This conclusion from Ross illustrates how it is more and more visible that Macbeth's image as a rightful leader is unsustainable. It eventually leads to the fomenting of a rebellion by Duncan's old allies.

At this point in the diegesis, accounting theory would predict two possible future outcomes. First, Macbeth could get away with the murders, by chance, if future events conceal his deceptions. Second, Macbeth could be forced to perpetuate deception and concealment, with increasing risks and consequences if discovered. The latter is observable in the play which, relying on accounting literature, could announce a tragic downfall.

And indeed, Macbeth's character finally collapses when the rebellion is concretised and the tyrant is conquered and killed by Macduff. It is therefore possible to assert that Macbeth's unsustainable fraudulent and misleading actions did predictably result, from an opportunistic perspective, in his 
downfall. The exaggeratedly favorable honorific equity he disclosed to the people who had a certain power over his own power - his former king, allies and subjects - was unsustainable and, when discovered, led to their fleeting or passing.

\section{Debt-Equity Hypothesis}

Diving more precisely into the opportunistic perspective, the gradual separation of the Macbeth couple also reveals a situation analogous to a debt/equity covenant constraint for Lady Macbeth, as she starts to depict a better personal situation to others than what she knows her honor to be worth, in order to preserve her status and privileges. However, once Duncan's murder is committed, her conscience slowly creeps up on her, and she is left to contemplate the despair in which she put herself: "Naught's had, all's spent,/Where our desire is got without content/'Tis safer to be which we destroy/Than by destruction dwell in doubtful joy" (III.ii.6-9). Caught in a deception spiral (analogous an unbearable business indebtedness), she does not inform her husband of what is on her mind, and therefore begins an isolated descent into distress, causing her to accumulate an undisclosed unstable state (a bankrupt mind) hidden from others within and outside the family (or entity).

Ultimately, the accumulation of misrepresented honor by both Macbeth and Lady Macbeth undermines their overall honorific equity, and thus power. They get eventually caught up by consequences: Lady Macbeth commits suicide, and it greatly affects Macbeth, who most likely did not see this "bankruptcy" coming. Metaphorically, an affiliated character goes bankrupt, thereby decreasing the whole entity's wealth, or wellbeing. Macbeth's disclosed and undisclosed tyranny was partly responsible for Lady Macbeth's suicide. Part of the couple's downfall can therefore be attributed to ever increasing impression management or pressure to manage impression in order to achieve family goals. Indeed, one could argue that the tragic end of Lady Macbeth would not have occurred had her husband always managed to accumulate honor within existing rules.

Another application of debt equity hypothesis to the couple's diegetic progression is remarkable in Macbeth's bloody actions. We note that Lady Macbeth also participates in the scheme at the beginning of the play, when malfeasance then seems benign. In order to conceal the immense honor liability that is Duncan's murder to his potential future subjects (stakeholders in accounting parlance), and therefore preserve his untainted reputation of "peerless kinsman" (I.iv.63), Macbeth starts by counterfeiting rage and despair at the discovery of Duncan's lifeless body: "Had I but died an hour before this chance,/I had lived a blessed time, for from this instant/There's nothing serious in mortality:/All is but toys: renown and grace is dead" (II.iii.99-102). Then, when Malclom and Donalbain flee in fear for their life, Macbeth continues his attempt to keep himself above suspicion (and therefore retain the social honor he has gained) by perpetuating the blame of the murder placed on them: "our bloody cousins are bestowed/In England and in Ireland, not confessing/Their cruel parricide" (III.i.33-35). By hiding his own culpability, Macbeth dissimulates dishonor to his entourage, and by nobly opposing himself to those who are suspected of horrendous acts, he deceitfully exaggerates his own honor. Finally, to assure the durability of his overly positive but fake honorific equity, Macbeth takes more drastic measures: he kills Banquo, the only witness of his encounter with the wayward sisters, and therefore the only potential "whistleblower" regarding the true state of his honorific equity. Banquo's murder is a success, but it is only the first of a long series of bloody attempts to maintain a glowing honorific equity which, with every murder, becomes more and more difficult to misrepresent. The misleading portrayal eventually becomes so fragile with implausibility that it shatters. Therefore, Macbeth's continuous lies eventually cause the failure of his enterprise.

\section{Anticipating Failure}

Accounting theory, as well as plenty of congruent empirical accounting literature, would suggest that, as the play progresses, the accumulation of misleading Macbeth family honor overstatements will, if not reversed or redressed, lead to a tragic downfall. And indeed the play concludes with the family's demise.

This series of illustrative applications of accounting theory to understand Macbeth provides support for our hypothesis that accounting theory can help to understand literature with a novel perspective inscribed in new economic criticism.

\section{CONCLUSION}

Accounting has long been known as the language of business. Powerful accounting theoretical frameworks have been developed to probe the use of accounting in the dialogue among a wide diversity of business stakeholders. The main contribution of this paper is to propose, for the very first time, that accounting theory could help to explore literary works through an abstraction process. The paper also provides empirical support through an analysis of Macbeth.

The closer we get to the commonality of the roots of accounting and literary intrigues, namely the human nature, the more promising the vast accounting theory literature appears to be to explain the construction of literary works. Indeed, using Macbeth as a setting in this paper was less intuitive and more challenging than using The Merchant of Venice, but nevertheless very fruitful.

The use of accounting theory to explore literature proposed in this paper opens doors to much more research. First, the enduring relevance of accounting since Pacioli's seminal work (1494) suggests that accounting theoretical lenses could prove useful in comparative literature contrasting works with settings very distant in time. Second, the malleability of the abstraction process exemplified in this paper could help business and literature researchers and students to find common grounds for interdisciplinary research and learning. Third, the accounting literature has developed its own vocabulary to qualify situations, interactions and outcomes regarding the interplay among several stakeholders 
(including owners, managers, regulators, activists, media, and society in general) which could prove useful to explain literary concepts and to develop new taxonomies of literary processes. Fourth, in the opposite direction, this paper opens doors to research on how literary theories could enrich accounting theory and accounting research. Accounting theorists have never been shy of borrowing from economic and psychological theorists but, as society evolves towards a need to consider pricelessness, literary concepts could enrich accounting thought further. Finally, this paper is an overture to broadened and cross-disciplinary contributions to new economic criticism.

This study implies many limitations. The most important one is in the subjectivity of the analogical abstraction process that the analysis uses, although adaptability can also be a strength. Another limitation is the selectivity we had to use to keep this paper concise. A comprehensive analysis of one of William Shakespeare's most famous tragedies through accounting theory lenses, with its numerous characters and acts, is possible but far beyond the scope of this exploratory study.

\section{REFERENCES}

Amariglio, J. (1990). Economics as a postmodern discourse. In Economics as discourse: An analysis of the language of economists. Ed. Samuels, W.J. Boston: Kluwer, $15-46$.

Avery, H.G. (1953). Accounting as a language. The Accounting Review 28(1) 83-87.

Ball, R. (2009). Market and political/regulatory perspectives on the recent accounting scandals. Journal of Accounting Research 47, 277-323. doi:10.1111/j.1475679X.2009.00325.x

Burgstahler, D. \& Dichev, I. (1997). Earnings management to avoid earnings decreases and losses. Journal of Accounting and Economics 24(1), 99-126.

Deegan, C.M. (2014). Financial accounting theory. $4^{\text {th }}$ ed. North Ryde, N.S.W. McGraw-Hill Education (Australia) Pty Ltd, 625 .

Dobski, B.J. \& Gish, D.A. (2011). Souls with longing: Representations of honor and love in Shakespeare. Lexington Books. 332 p.

Erikson, M., Hanlon, M. \& Maydew, E.L. (2006). Is there a link between executive equity incentives and accounting fraud? Journal of Accounting Research 44(1), 113-143.

Fogel, K. (2006). Oligarchic family control, social economic outcomes, and the quality of government. Journal of International Business Studies, 37(5), 603-622.

Healy, P.M. \& Wahlen, J.M. (1999). A review of the earnings management literature and its implications for standard setting. Accounting Horizons 13 (4, December), 365-383.

Healy, P.M. \&. Palepu, K.G. (2003). The fall of Enron. The Journal of Economic Perspectives 17(2), 3-26.

Heinzelman, K. (1980). The economics of the imagination. Amherst University of Massachusetts, Amherst, $236 \mathrm{p}$.

Jameson, F. (1991). Postmodernism, or, the cultural logic of late capitalism. Durham: Duke University Press.
Jensen, M.C. \& Meckling, W.H. (1976). Theory of the firm: Managerial behavior, agency costs and ownership structure. Journal of Financial Economics, 3(4), 305-360.

Kapur, S. \& Mohanty P. (2014). Lessons from literature: Blending academic perspective with management practices, Advances in Language and Literary Studies 5(5), 233-238.

Karpoff, J., Lee, D. \& Martin, G. (2008). The cost to firms of cooking the books. Journal of Financial and Quantitative Analysis, 43(3), 581-611. doi:10.1017/ S0022109000004221

Kaufmann, D. (1995). The business of common life: Novels and classical economics between revolution and reform. Baltimore: The Johns Hopkins University Press.

Klamer, A., McCloskey D.N. \& Solow, R.M., eds. (1988). The consequences of economic rhetoric. Cambridge University Press. Cambridge.

Korda, N. (2009). Dame usury: Gender, credit, and (ac) counting in the sonnets and "The Merchant of Venice". Shakespeare Quarterly, Vol. 60(2, Summer), 129-153.

McCloskey, D.N. (1985). The rhetoric of economics. Madison: University of Wisconsin Press.

Pacioli, L. (1494). Summa de arithmetica, geometria, proportioni et proportionalita; distintio nona-tranctatus XI, particularis de computis et scripturis. Paganino de Paganini, Venice. Translated by Brown, R.G. \& Johnston, K.S. (1963), Paciolo on accounting.

Pigou, A. C. (1917). The value of money. The Quarterly Journal of Economics 32(1), 38-65.

Purdy, A., ed. (1993). Literature and money. Amsterdam and Atlanta: Rodopi.

Raman, S. (2005). Marking time: Memory and market in "The Comedy of Errors". Shakespeare Quarterly 56(2, Summer), 176-205.

Resnick, S. \& Wolff, R. 1988. Marxian theory and the rhetorics of economics. In The consequences of economic rhetoric. Ed. Klamer A., McCloskey, D.N. and Solow, R.M. Cambridge: Cambridge University Press, 47-63.

Rossi-Landi, F. (1975). Linguistics and economics. The Hague: Mouton.

Sangster, A., Stoner, G.N., \& McCarthy P.A. (2007). Lessons for the classroom from Luca Pacioli. Issues in Accounting Education 22(3), 447-457.

Sangster, A. (2016). The genesis of double entry bookkeeping. The Accounting Review 91(1), 299-315.

Schrand, C. M. \& Zechman, S.L.C. (2012). Executive overconfidence and the slippery slope to financial misreporting. Journal of Accounting and Economics, 53(1), 311-329.

Shakespeare, W. (1600). The merchant of Venice. London.

Shakespeare, W. (2009). Macbeth, Ed. Bate, J. \& Rasmussen, E., The Modern Library, New York, 190 p.

Shell, M. (1978). The economy of literature. Johns Hopkins University Press, Baltimore, $176 \mathrm{p}$.

Shell, M. (1982). Money, language and thought: Literary and philosophical economies from the medieval to the modern era. Berkeley: University of California Press. 
Shell, M. (1995). Art and Money. University of Chicago Press, Chicago.

Sheppard, J. (1994). The corporate moral person: The organization's personality and its board. Journal of Business \& Society 7(2), 151-164

Solow, R. M. (1988). Comments from inside economics. In The consequences of economic rhetoric. Ed. Klamer, A., McCloskey, D.N. \& Solow, R.M. Cambridge: Cambridge University Press, 31-37.

Watson, C. B. (1960). Shakespeare and the renaissance concept of honor. Princeton University Press. 490p.

Watts, R. L. \& Zimmerman, J.L. (1986). Positive Accounting Theory. Englewood Cliffs, N.J. Prentice-Hall.
West, C. (2016). The merchant of Venice/William Shakespeare. Oxford, United Kingdom: Oxford University Press.

Woodbridge, L. (2003). Money and the age of Shakespeare: Essays in new economic criticism, Palgrave MacMillan, England.

Woodmansee, M. \& Osteen, M. (1999). The new economic criticism: Studies at the intersection of literature and economics. Routledge, London and New York.

Zang, A. Y. (2011). Evidence on the trade-off between real activities manipulation and accrual-based earnings management. The Accounting Review, Vol. 87(2), 675-703. 